\title{
CALIPSO and sunphotometer measurements of Saharan dust events over Camagüey
}

\section{Mediciones de eventos de polvo del Sahara con CALIPSO y fotómetro solar sobre Camagüey}

\author{
R. Estevan $\left(1,{ }^{(*)}\right.$, L. Mona(2), N. Papagiannopoulos ${ }^{(2)}$, J.C. Antuña ${ }^{(1)}$, \\ V. Cachorro( $(3, \mathrm{~S})$, Á. de Frutos $(3, \mathrm{~S})$
}

1. Grupo de Óptica Atmosférica de Camagüey, Instituto de Meteorología, Camagüey, Cuba.

2. Consiglio Nazionale delle Ricerche, Istituto di Metodologie per l'Analisi Ambientale (CNR-IMAA), Potenza, Italy

3. Grupo de Óptica Atmosférica, Universidad de Valladolid, Valladolid, Spain.

\author{
(*) Email: realcmw@gmail.com \\ S: miembro de SEDOPTICA / SEDOPTICA member \\ Received / Recibido: 15/02/2014. Revised / Revisado: 04/06/2014. Accepted / Aceptado: 22/08/2014. \\ DOI: http://dx.doi.org/10.7149/OPA.47.3.189
}

\begin{abstract}
:
Large volumes of Saharan dust particles are transported each year from northern Africa to the Americas, through Atlantic Ocean, reaching during the northern hemisphere summer the Wider Caribbean and Cuba in particular. Since the installation in October 2008 of a sun photometer type CIMEL CE-318, operated by Atmospheric Optics Group of Camagüey, numerous Saharan dust events have been registered. The most significant events for this AERONET measurement site were registered during July 2009. The highest AOD value with a magnitude greater than 0.6 was reported on July 6 . The longest event for this period occurred between 15 and 20 July, with maximum AOD values above of 0.6. Measurement performed with lidar aboard CALIPSO satellite, for coincident measurement on July 19, distant $22.6 \mathrm{~km}$ to west of sun photometer site, provide information about the space-temporal distribution of this event. The AOD registered values of 0.35 and 0.32 for both, CALIPSO and MODIS, respectively, have equal magnitude than CIMEL measurement for the same day. The intercomparison between instruments, with different measurement principles, has corroborated its complementarity. CALIPSO, MODIS and AERONET data available at global scale are used, in conjunction with transport models and backtrajectories, for investigating the Saharan dust plume dispersion.
\end{abstract}

Key words: CALIPSO, CIMEL, MODIS, EARLINET, Lidar, Sunphotometer, Saharan Dust, Aerosol.

\section{RESUMEN:}

Grandes volúmenes de partículas de polvo del Sáhara son transportadas cada año desde el norte de África hacia las Américas, a través del Océano Atlántico, alcanzando durante el verano del hemisferio norte el Gran Caribe y Cuba en particular. Desde la instalación, en Octubre de 2008 de un fotómetro solar del tipo CIMEL CE-318, operado por el Grupo de Óptica Atmosférica de Camagüey, numerosos eventos de polvo del Sáhara han sido registrados. El evento más significativo para este sitio de mediciones de AERONET fue registrado durante Julio de 2009. Los mayores valores de AOD con una magnitud superior a 0.6 fue reportado el 6 de Julio. El evento más extenso para este período ocurrió entre el 15 y el 20 de Julio, con valores máximos de AOD por encima de 0.6. Las mediciones realizadas con el lidar a bordo del satélite CALIPSO, para mediciones coincidentes el 19 de Julio, distante $22.6 \mathrm{~km}$ al oeste del sitio del fotómetro solar, ha suministrado información sobre la distribución espacio-temporal de este evento. Los valores de AOD de 0.35 y 0.32 , registrados por CALIPSO y MODIS, respectivamente, tienen igual magnitud que las mediciones del CIMEL para el mismo día. La intercomparación entre instrumentos, con diferentes principios de medicines, ha corroborado su complementaridad. En el mismo período, Europa fue también afectada por eventos de polvo del Sahara. Los datos disponibles a escala global de CALIPSO, MODIS y AERONET son 
usados, en conjunto con modelos de transporte y retrotrayectorias, para investigar la dispersión de la masa de polvo del Sahara.

Palabras clave: CALIPSO, CIMEL, MODIS, Lidar, Fotómetro Solar, Polvo del Sáhara, Aerosoles.

\section{REFERENCES AND LINKS / REFERENCIAS Y ENLACES}

[1]. IPCC. Climate Change 2007: The Physical Science Basis. Contribution of Working Group I to the Fourth Assessment Report of the Intergovernmental Panel on Climate Change, Cambridge University Press, Cambridge, United Kingdom and New York, NY, USA (2007).

[2]. R. Estevan, J.C. Antuña, B. Barja, V. E. Cachorro, A. M. de Frutos, A. Berjón, C. Toledano, B. Torres, R. Rodrígo, T. A. Hernández, C. E. Hernández, "Preliminary results of aerosols measurements with sun photometer at Camagüey, Cuba”, Opt. Pura Apl. 44, 99-106 (2011).

[3]. B. N. Holben, T. F. Eck, I. Slutsker, D. Tanré, J. P. Buis, A. Setzer, E. F. Vermote, J. A. Reagan, Y. J. Kaufman, T. Nakajima, F. Lavenu, I. Jankowiak, A. Smirnov, "AERONET: A federated instrument network and data archive for aerosol characterization", Remote Sens. Environ. 66, 1-16 (1998). DOI

[4]. B. N. Holben, D. Tanré, A. Smirnov, T. F. Eck, I. Slutsker, N. Abuhassan, W. W. Newcomb, J. S. Schafer, B. Chatenet, F. Lavenu, Y. J. Kaufman, J. Vande Castle, A. Setzer, B. Markham, D. Clark, R. Frouin, R. Halthore, A. Karneli, N. T. O'Neill, C. Pietras, R. T. Pinker, K. Voss, G. Zibordi, “An emerging groundbased aerosol climatology: Aerosol Optical Depth from AERONET", J. Geophys. Res. 106, 12067-12097 (2001). DOI

[5]. D. M. Winker, W. H. Hunt, M. J. McGill, "Initial performance assessment of CALIOP”, Geophys. Res. Lett. 34, L19803 (2007). DOI

[6]. D. Winker, J. Pelon, J. A. Coakley Jr., S. A. Ackerman, R. J. Charlson, P. R. Colarco, P. Flamant, Q. Fu, R. M. Hoff, C. Kittaka, T. L. Kubar, H. Le Treut, M. P. McCormick, G. Mégie, L. Poole, K. Powell, K. Trepte, M. A. Vaughan, B. A. Wielicki, "The CALIPSO mission: A global 3D view of aerosols and clouds", Bull. Amer. Meteor. Soc. 91, 1211-1229 (2010). DOI

[7]. M. A. Vaughan, K. A. Powell, R. E. Kuehn, S. A. Young, D. M. Winker, C. A. Hostetler, W. H. Hunt, Z. Liu, M. J. Mcgill, B. J. Getzewich, "Fully automated detection of cloud and aerosol layers in the CALIPSO lidar measurements", J. Atmos. Ocean. Technol. 26, 2034-2050 (2009). DOI

[8]. S. A. Young, M. A. Vaughan, "The retrieval of profiles of particulate extinction from cloud-aerosol lidar infrared pathfinder satellite observations (CALIPSO) data: Algorithm description", J. Atmos. Ocean. Technol. 26, 1105-1119 (2009). DOI

[9]. Z. Liu, R. Kuehn, M. Vaughan, D. Winker, A. Omar, K. Powell, C. Trepte, Y. Hu, C. Hostetler, “The CALIPSO cloud and aerosol discrimination: Version 3 algorithm and test results", Proceeding of $25^{\text {th }}$ International Laser Radar Conference (ILRC), St. Petersburg, Russia, 4 pp (2010).

[10].Z. Liu, D. Winker, A. Omar, M. Vaughan, C. Trepte, Y. Hu, K. Powell, W. Sun, B. Lin, "Effective lidar ratios of dense dust layers over North Africa derived from the CALIOP measurements", J. Quant. Spectrosc. Rad. 112, 204-213 (2011). DOI

[11].Z. Liu, A. Omar, M. Vaughan, J. Hair, C. Kittaka, Y. Hu, K. Powell, C. Trepte, D. Winker, C. Hostetler, R. Ferrare, R. Pierce, "CALIPSO lidar observations of the optical properties of Saharan dust: a case study of long-range transport”, J. Geophys. Res. 113, D07207 (2008).

[12]. I. Uno, K. Yumimoto, A. Shimizu, Y. Hara, N. Sugimoto, Z. Wang, Z. Liu, D. M. Winker, "3D structure of Asian dust transport revealed by CALIPSO lidar and a 4DVAR dust model”, Geophys. Res. Lett. 35, L06803 (2008). DOI

[13]. A. Omar, Z. Liu, M. Vaughan, K. Thornhill, C. Kittaka, S. Ismail, Y. Hu, G. Chen, K. Powell, D. Winker, C. Trepte, E. Winstead, B. Anderson, "Extinction-to-backscatter ratios of Saharan dust layers derived from in situ measurements and CALIPSO overflights during NAMMA", J. Geophys. Res. 115, D24217 (2010). DOI

[14]. L. Mona, Z. Liu, D. Müller, A. Omar, A. Papayannis, G. Pappalardo, N. Sugimoto, M. Vaughan, "Lidar measurements for desert dust characterization: An overview", Adv. Meteorol. 2012, 356265 (2012). $\underline{\text { DOI }}$ 
[15]. L. A. Remer, Y. J. Kaufman, D. Tanre, S. Mattoo, D. A. Chu, J. V. Martins, R. R. Li, C. Ichoku, R. C. Levy, R. G. Kleidman, T. F. Eck, E. Vermote, B. N. Holben, "The MODIS aerosol algorithm, products, and validation", J. Atmos. Sci. 62, 947-973 (2005). DOI

[16]. Y. J. Kaufman, A. E. Wald, L. A. Remer, B. C. Gao, R. R. Li, L. Flynn, "The modis 2.1-mm channelcorrelation with visible reflectance for use in remote sensing of aerosol", IEEE T. Geosci. Remote 35, 1286-1298 (1997). DOI

[17].Y. S. Bennouna, V. E. Cachorro, B. Torres, C. Toledano, A. Berjón, A. M. de Frutos, I. Alonso. "Atmospheric turbidity determined by the annual cycle of the aerosol optical depth over north-center Spain from ground (AERONET) and satellite (MODIS)", Atmos. Environ. 67, 352-364 (2013). DOI

[18]. G. Lesins, U. Lohmann. "Using MODIS and AERONET to determine GCM aerosol size", J. Atmos. Sci. 63, 1338-1347 (2006). DOI

[19]. LAADS, Level 1 and Atmosphere Archive and Distribution System, http://ladsweb.nascom.nasa.gov

[20]. R. R. Draxler, G. D. Rolph. "HYSPLIT (Hybrid Single-Particle Trajectory). Model access via NOAA ARL READY Website", NOAA Air Resources Laboratory, Silver Spring, MD (2003).

[21]. A. H. Omar, D. M. Winker, J. L. Tackett, D. M. Giles, J. Kar, Z. Liu, M. A. Vaughan, K. A. Powell, C. R. Trepte, "CALIOP and AERONET aerosol optical depth comparisons: One size fits none", J. Geophys. Res. 118, 4748-4766 (2013).

[22]. J. C. Antuña, V. Cachorro, R. Estevan, Á. de Frutos, B. Barja, Y. Benouna, B. Torres, D. Fuertes, R. González, C. Toledano, G. Kallos, S. Cristos, "Characterizing aerosol optical depth measurements and forecasts of Saharan dust events at Camagüey, Cuba, during July 2009”, Opt. Pura Apl. 45, 415-421 (2012). DOI

[23].X. Ma, K. Bartlett, K. Harmon, F. Yu, "Comparison of AOD between CALIPSO and MODIS: Significant differences over major dust and biomass burning regions", Atmos. Meas. Tech. 6, 2391-2401 (2013). $\underline{\text { DOI }}$

\section{Introduction}

The still large uncertainties of atmospheric aerosol role, in a wide range of process such as the global radiation balance, have been recognized through international panels [1]. The permanent interest in the atmospheric aerosols, cause the development and use of different techniques for its studies. The implementation of monitoring networks, such as AERONET, EARLINET and much more, is also an example of the importance of this atmospheric constituent.

Within the extensive atmospheric aerosols types, the Saharan Dust remarks a growing interest due the important role on climate in general, and on chemical, physical and biological processes, as well as, health and human activities in particular.

The variability of Saharan dust optical properties, transported across the Atlantic to the Caribbean, has been poorly studied. A sunphotometer has been functioning at Camagüey, Cuba since the end of 2008, operated by Atmospheric Optics Group of Camagüey (GOAC, in Spanish) [2]. This sunphotometer belongs to RIMA (Iberian Network for Aerosols
Measurements) under GOA-UVA leadership, and its measurements are contributed to the Aerosol Robotic Network (AERONET). The collected information has been used for preliminary studies and new studies are under way by GOAC, including the characterization of the variability of the Saharan dust optical properties during the transport from its sources to the Caribbean.

One of proposed objectives for present work is the CALIPSO data analysis assimilation and their comparison with ground based instruments like sunphotometers at Camagüey, as well as, with other instruments aboard satellites. For such a reason a case study has been selected with Saharan dust intrusion over Camagüey, Cuba. In parallel, the possible effect by the same event over Europe, constitute another objective for this work.

\section{Instrument and dataset}

A sunphotometer CIMEL CE-318 is operated by the GOAC since October 2008 [2]. This instrument is an automatic multi-spectral sun tracking photometer, designed for very accurate sun measurements. The CIMEL CE-318 is the 


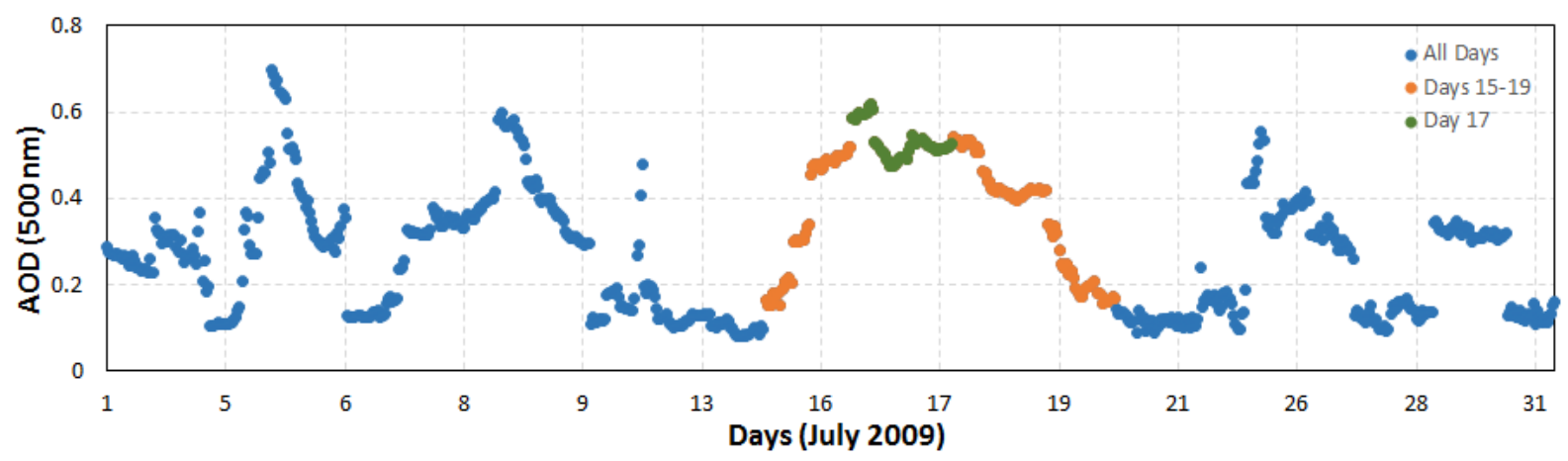

Fig. 1. Time evolution of AOD (500 nm) sunphotometer measurements during July, 2009 (blue points). Orange points correspond to longest Saharan Dust event into the month, considered as the case study period, and the green points are related with the maximum AOD value (0.615) inside the case study period.

standard instrument of AERONET for sun direct irradiance and sky radiance measurements $[3,4]$. In the present study will be used the Aerosol Optical Depth (AOD) values corresponding to $500 \mathrm{~nm}$ channel and the Angstrom Parameter in the range of $440-870 \mathrm{~nm}$, as well as, derived inversion products from almucantar scenarios, such as particle size distribution volume. Up to the present days, six sunphotometers have operated at Camagüey location. Between June 4, 2009 and April 23, 2010, the sunphotometer \#343 has been used on GOAC site, producing a total of 312 days of raw measurements (Level 1.0, according with the AERONET standards). After the sunphotometer post-calibration procedure, indispensable step to reach the Level 2.0, a total of 277 days achieve this level, representing the $88.78 \%$.

Several Saharan dust events occurred during the exploitation period of this instrument. The most active period since October 2008 until now, took place on July 2009 (Fig. 1). Within this month was registered the longer event in time up to now, taken place between July 15 and 20 (Fig. 1, orange points), which will be the study object of the present work.

The Cloud-Aerosol LIdar with Orthogonal Polarization (CALIOP) instrument is the main instrument aboard the Cloud-Aerosol Lidar and Infrared Pathfinder Satellite Observations (CALIPSO) satellite.

This instrument was designed to acquire vertical profiles of elastic backscatter with a lidar at two wavelengths (1064 and $532 \mathrm{~nm}$ ) with dualpolarization [5,6]. From the total backscatter coefficient measurements are derived both, aerosol and cloud heights, as well as, the retrievals of extinction coefficient profiles $[7,8]$. Different algorithms in conjunction with depolarization technique are employ in the version 3 of CALIPSO data products, in order to enable the accurate discrimination between aerosols and clouds $[9,10]$.

Since the beginning of the scientist measurements in June 2006, the CALIPSO measurements demonstrated their potentiality for the aerosols studies, in particular for dust studies, for regional and global scales. The quality of such measurements has been widely documented (e.g. [11, 12, 13, 14]). To compare the CALIOP data and sunphotometer ground measurements, will be use the AOD values derived from the lidar signal at $532 \mathrm{~nm}$, acquired during the nights and corresponding to data release version 3.01.

In order to corroborate the AOD values derived from CIMEL and CALIPSO, the dataset produced by the instrument Moderate Resolution Imaging Spectroradiometer (MODIS) are used. This sensor, aboard the NASA Earth Observing System (EOS) Terra and Aqua satellites, provide aerosol observations during satellite overpass. Aerosols optical and physical parameters, such as the AOD and Angstrom exponent over land and ocean, are derived from such measurements [15]. MODIS aerosol retrievals over land and ocean are separate using two independent algorithms [16]. Several authors $[17,18]$ have addressed the effectiveness of MODIS and sunphotometer intercomparison.

For quantitative comparison purpose a 25 $\mathrm{km}$ spatial criteria has been used as well as 
derived AOD at $550 \mathrm{~nm}$ on July 19, from MODIS 5.1 collection version. The employed MODIS dataset correspond to Level 2 aerosol products MOD04 (Terra) and MYD04 (Aqua), which provide aerosol observations at satellite overpass over Camagüey region, available at LAADS [19].

\section{Results}

The AOD ground measurements, carry out with the sunphotometer CIMEL by the GOAC, has permitted to characterize the Camagüey site as maritime mixed [2]. Nevertheless, the occurrence of dust events during the north hemisphere summer disrupt the normal pattern of the background condition of tropospheric aerosols concentrations. An important example of these phenomenon were held during the summer of 2009, specifically on July, when several Saharan Dust events occurred during this month. The maximum AOD value of 0.696 took place on July 6 at 11:53:26 UTC (Fig. 1). The maximum AOD value during the case study period (Fig. 1, green points), was 0.615 on July 17 at 12:20:13 UTC.

To analyze the aerosols characteristics affecting Camagüey site during July 2009, we use the Angstrom Parameter (AP), commonly represented by alpha symbol $(\alpha)$, in the range of 440 to $870 \mathrm{~nm}$, as well as, the volume particles size distribution. As can be appreciated on the AOD-AP scattergram shown in Fig. 2, it is significant that all AP values for July 2009 are lower than one. The $63 \%$ of AP took values under 0.4, which implies large particles, reaffirms the preponderance of dust aerosol during this month.

The region located within AOD values below 0.2 and $\mathrm{AP}$ in the range from 0.2 to 1.0 correspond to maritime aerosols. A small sector within the figure, among 0.2 and 0.4 AOD values and AP between 0.6 and 1.0 can be considered as mixed, as polluted aerosols intruded into the region of Camagüey. Most of the values corresponding to the case study period (Fig. 2, orange points) are found below the AP

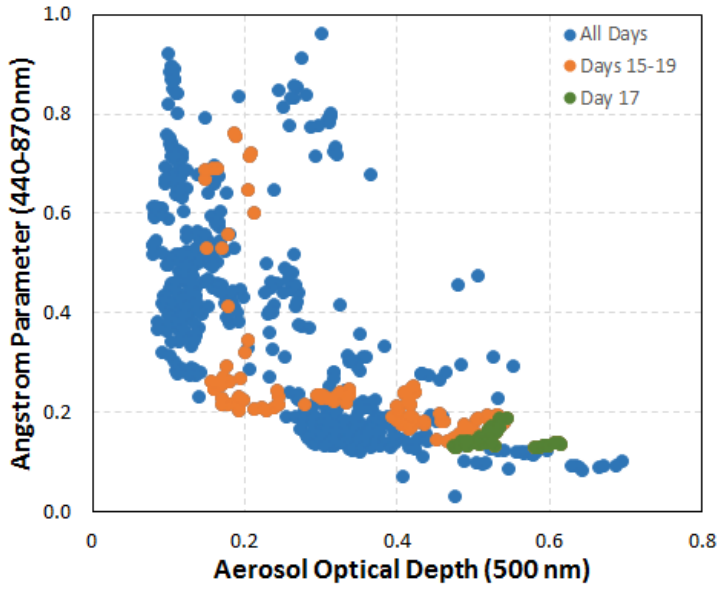

Fig. 2. Scattergram of Angstrom Parameter (440-870 nm) versus AOD (500 $\mathrm{nm}$ ) for all CIMEL measurements on July 2009 (blue points), for the case study period 15 to 19 of July (orange points) and the maximum value into the case study (July 17, green points).

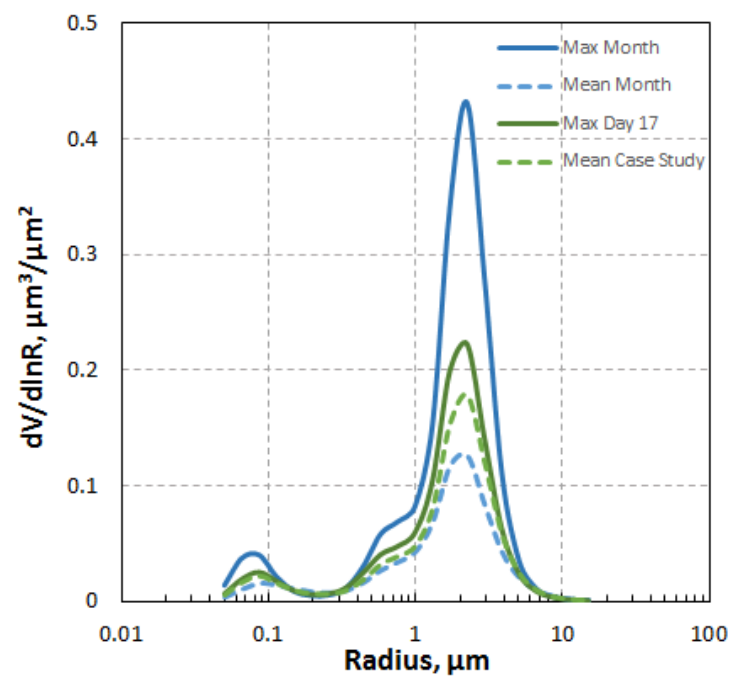

Fig. 3. Volume particles size distributions derived from inversion procedure on July 2009. Averaged values for month (blue dashed lines) and for case study period (green dashed line). Continuous lines correspond days with maximum AOD values for month (blue line) and case study period July 17 (green line).

magnitude of 0.4 , only July 15 have values above this magnitude.

The almost absolute coarse monomodal distribution of volume particle size distribution for July 2009 can be observed in Fig. 3. The average coarse mode is centered on $2.24 \mu \mathrm{m}$ with a monthly average value of $0.13 \mu \mathrm{m}^{3} / \mu \mathrm{m}^{2}$. However, for the study object period we found 

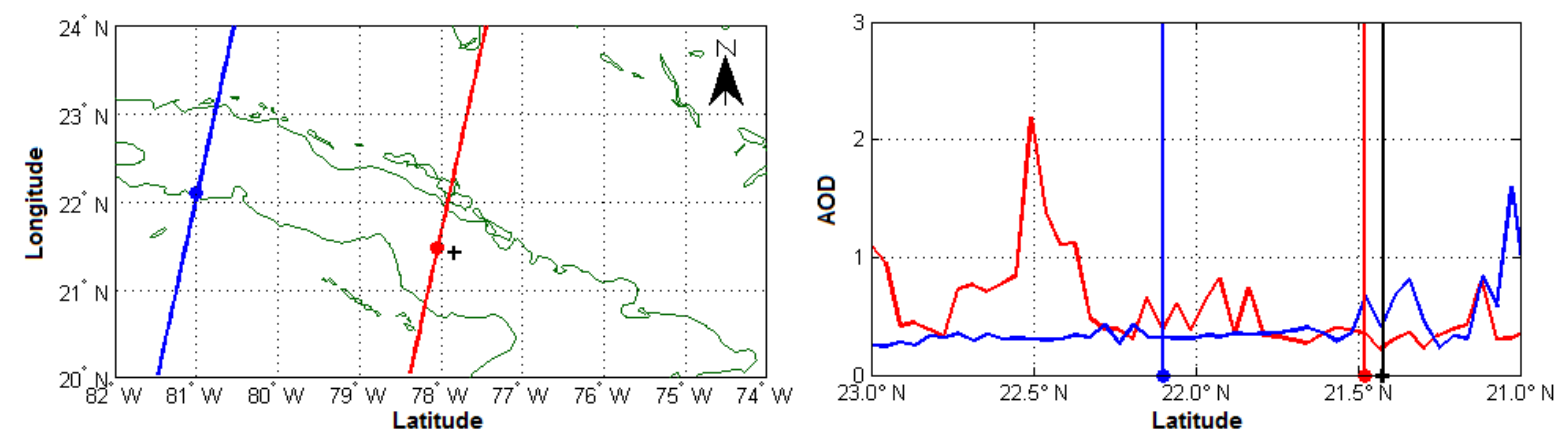

Fig. 4. CALIPSO coincident measurements, nighttime, for July 17 (blue line) and July 19 (red line). Overpass trajectories are represented on the left panel, as well as the nearest point (filled circles) to Camagüey coordinates (black cross). Also in this panel is represented by a brown dashed line box the grid formed by MODIS retrievals for July 19. On right panel the AOD values corresponding to the two CALIPSO overpass cross section, the closest point are represented by vertical lines for both cases.

high volume concentrations of large particles, except for July 16 where the volume only reaches a value of $0.024 \mu \mathrm{m}^{3} / \mu \mathrm{m}^{2}$ for radius of $2.24 \mu \mathrm{m}$. For the rest of days into the mentioned period, volume concentrations on the same radius value are between 0.2 and $0.29 \mu \mathrm{m}^{3} / \mu \mathrm{m}^{2}$.

From the previous analysis we can ensure, based on the optical properties characteristics, the prevalence of Saharan Dust aerosols during July 2009. In the case of the study period, results shown that the high AOD values between July 15 and 19 are related to the presence of Saharan dust. Nevertheless for July 15, everything seems to indicate the presence of dust mixture, taking into account the relatively high values of $\mathrm{AP}$, although it only reaching 0.75 still under the unit.

With the objective to corroborate the origin of aerosols affecting Camagüey site in the study period, we use the HYSPLIT trajectory model from NOAA [20]. Running a backward trajectory (not shown), starting on July 13 and ending at 12:00 UTC of July 19 can be confirm the origin of aerosol dust on Saharan region at the level of 3 $\mathrm{km}$. Lower levels have their origin over ocean.

\section{3.a Coincident CALIPSO comparison}

The closest CALIPSO trajectory, for the maximum value in the case study (July 17), took place to $334.9 \mathrm{~km}$ westward of the GOAC site, at 7:25:35 UTC (Fig. 4, blue line on left panel). That means 4:54:38 hours earlier than the sunphotometer measurement, with an AOD value of 0.32 , almost the half of CIMEL value for the same day.
The better CALIPSO space-temporal coincidence correspond to a measurement carry out on July 19 . The sunphotometer measurement was made at 11:49:39 UTC, with $\mathrm{AOD}=0.34$. The nearest CALIPSO overpass took place 04:36:18 hours before than sunphotometer measurement, to a distance of $22.61 \mathrm{~km}$ to west northwest of CIMEL site, with an AOD value of 0.35 (Fig. 4, right panel, red line). In this case, a good agreement between the two instruments have found, however in similar comparisons [21], the temporal criteria is the half than the here obtained.

From the CALIPSO data products analysis, can be deduced that the aerosol mass arriving to Cuba since July 15, left the African continent on July 11 with a longitudinal extension of more than $2900 \mathrm{~km}$, more than $5 \mathrm{~km}$ of thickness and reaching $6.3 \mathrm{~km}$ height. The averaged maximum AOD value for the aerosol mass was 0.92 with absolute maximum value near to 3.0 upon leaving the continent.

On July 19, the Saharan dust mass over Camagüey, Cuba, took a longitudinal extension around $1190 \mathrm{~km}$, less than one half of what observed on the African coast. Regarding to the altitude over Camagüey, the dust cloud only reaches $4.5 \mathrm{~km}$ of height and around of $3.2 \mathrm{~km}$ of thickness, also in this case, practically $50 \%$ of the original dust mass due the existence of a gap, up to $\approx 1.1 \mathrm{~km}$ of altitude, around Camagüey site position.

After dust mass cross the Atlantic Ocean and reach the Caribbean Sea, the CALIPSO AOD 


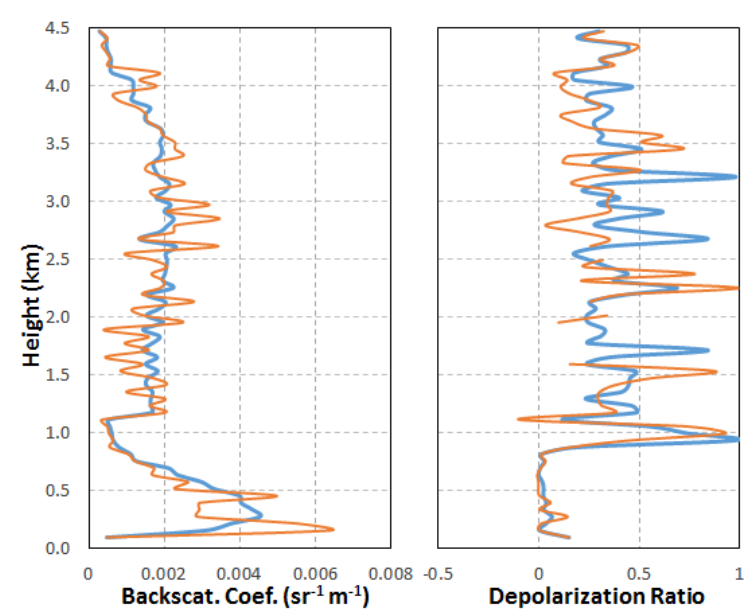

Fig. 5: Aerosol Backscatter Coefficient at $532 \mathrm{~nm}$ (left panel) and Depolarization Ratio (right panel) for CALIPSO nearest point on July 19 (orange line). Blue line represent the average values up to $\pm 15 \mathrm{~km}$ before and after the coincident point.

maximum mean values over Camagüey, on July 19 , are in the range of 0.48 , while the maximun absolute value around 2.5 . It is important to point out that during the Atlantic crossing, the aerosols mass not only vary the geometric and morphologic characteristics, but their composition. About this aspect, the Aerosol Subtype CALIPSO data products identifies over Camagüey the presence of polluted dust subtype.

The aerosol mass optical characteristics over Camagüey are represented through the aerosol backscatter coefficient profile and the depolarization ratio profile (Fig. 5, left and right panels, respectively). The blue line in Fig 5 represents the average profiles calculated from $15 \mathrm{~km}$ before and after of CALIPSO coincident point on July 19, whose profile is represented by the orange line.

It is can be seen the presence of Saharan dust from $\approx 1.1 \mathrm{~km}$ of altitude for both backscatter profiles, average (smoothed) and the coincident point (noisy). Then the aerosol dust layer is clearly shown from $\approx 1.1 \mathrm{~km}$ to $\approx 4.1 \mathrm{~km}$, with the maximum concentration between 2.5 and $3.0 \mathrm{~km}$ in both cases.

The Saharan dust layer its well identified above $1 \mathrm{~km}$, from the analysis of the depolarization ratio profiles (Fig. 5, right panel). Differently from backscatter profiles, both depolarization ratio profiles are very noise, however around the inflection point a good agree can be appreciated. The mean value of depolarization ratio starting from $1 \mathrm{~km}$ is about $39 \%$, value that correspond to non-spherical particles, as Saharan dust particles. Bellow $1 \mathrm{~km}$ presence of Planetary Boundary Layer (PBL) are fine represented, aerosols backscatter coefficient with not to high values $\approx 4 \times 10^{-3} \mathrm{sr}^{-1} \mathrm{~m}^{-1}$ and very small values of depolarization ratio around, related with small and spherical particles. The analysis of both dataset, CIMEL and CALIPSO for 19 of July, 2009, have corroborated the presence of Saharan dust aerosols over Camagüey for July 19, 2009. The optical parameters analysis for both instruments represent very well the aerosol dust characteristic, through different approaches and methods.

To compare CALIPSO and ground AOD measurement with another source of spatial information, MODIS aerosols products are used. For consistency with sunphotometer results MODIS AOD at $550 \mathrm{~nm}$ is used. To represent the MODIS AOD over the site location, spatial subsets of Terra and Aqua data were extracted to select pixels within a distance of $25 \mathrm{~km}$ from the Camagüey site. The AOD values are spatially averaged to obtain a coincident AOD retrieval. The resulting AOD mean value 0.26 from Aqua, have better agreement with the results here reported for sunphotometer and CALIPSO on Camagüey location than Terra. The AOD value of 0.19 from Terra satellite, at the same wavelength, differs widely from its similar instrument aboard Aqua satellite and from ground and CALIPSO measurements.

The differences between Terra and Aqua AOD average values are not very significant when long-term statistical procedures are employed. In this sense, better results in the comparison between sunphotometer and MODIS AOD values for Camagüey, was obtained when daily mean values are employed, according with previous analysis accomplished for July 2009 [22]. Also in the previous study has been stated that the spatial mean MODIS AOD values (both, Terra and Aqua) underestimates the high aerosols concentrations and overestimates the lower ones, measured by the sun-photometer in Camagüey location. Other studies [23] refer than, in generally, CALIPSO AOD is lower than MODIS AOD, mainly during Saharan dust season, 
in contrast with reported here. However, must be taken into account that here we analyze a case study only.

\section{Conclusions}

The present work is the first attempt to compare aerosol measurements from CIMEL sunphotometer and CALIOP at Camagüey site. Results show a good agreement between AOD values for both instruments in the selected case. The spatial criteria has been determinant at the moment to select coincident CALIPSO overpass, regardless the temporal criteria.

The aerosol optical parameters derived from both instruments indicate the desert dust character of aerosols measured during the case study. The backtrajectories analysis, as well as, the physical and optical parameters for the different instruments used in this study, confirm the Saharan origin of aerosols on Camagüey during the analyzed period.

The coincident MODIS AOD values are lower than obtained here in both cases, Terra and Aqua. This result agree with previous intercomparison between CIMEL sunphotometer and MODIS for Camagüey location.

\section{Acknowledgements}

The financial support by the European Community through the ACTRIS Research Infrastructure Action under the 7th Framework Programme under ACTRIS Grant Agreement ${ }^{\circ}$ 262254 is gratefully acknowledged.

CALIPSO, MODIS and AERONET scientific teams and PI's are gratefully acknowledged for providing high quality data. 